ELORE (ISSN 1456-3010), vol. $16-2 / 2009$.

Julkaisija: Suomen Kansantietouden Tutkijain Seura ry.

[http://www.elore.fi/arkisto/2_09/ajankoht_anttila_2_09.pdf]

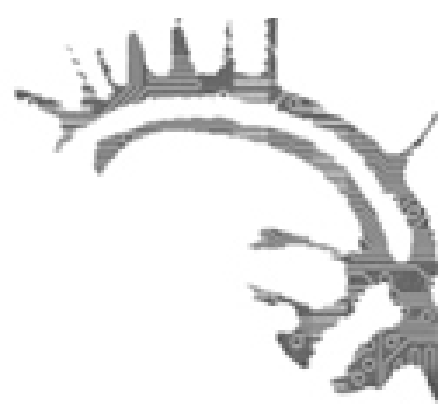

\title{
Ajankohtaista
}

\section{VARHAISNUORTEN SEURUSTELU TYTTÖJEN JA POIKIEN ROMANTTISENA KULTTUURINA}

\author{
$\underline{\text { Anna Anttila }}$
}

Lectio praecursoria Helsingin yliopistossa 20.11.2009

Lapsuus koskettaa meistä jokaista, olemmehan kaikki joko entisiä tai nykyisiä lapsia. Lapsuus on elämänvaiheista tärkein ja ainoa, joka varmuudella kuuluu kaikkien ihmisten elinkaareen, sen yksilöllisestä pituudesta riippumatta.

Kuluva vuosi on moninkertainen lapsuuden juhlavuosi. Lapsen oikeuksien julistus esitettiin Yhdistyneiden kansakuntien yleiskokouksessa päivälleen viisikymmentä vuotta sitten. Kansainvälisestä YK:n lasten vuodesta on myös kulunut tasavuosia, kolmekymmentä, ja YK:n lapsen oikeuksien yleissopimuksen solmimisestakin tänään tasan kaksikymmentä vuotta. Sopimuksen ovat allekirjoittaneet kaikki maat lukuun ottamatta kahta - Somaliaa ja Amerikan Yhdysvaltoja. Sopimusvaltioiden lainsäädännössä on muun muassa säädetty, että lapsilla - siis kaikilla alle 18-vuotiailla tytöillä ja pojilla - on oikeus osallistua heitä itseään koskevaan päätöksentekoon. Lapsen oikeuksien sopimuksella on taattu lapselle myös lainvoimainen oikeus lepoon ja vapaa-aikaan, hänen ikänsä mukaiseen leikkimiseen sekä vapaaseen osallistumiseen kulttuurielämään ja taiteisiin.

Miten alaikäisen suomalaisen osallistuminen kulttuuriin ja leikkiin käytännössä tapahtuu - ja kenen kanssa? Ei ainakaan oman perheen, jos mitataan aikaa, jonka lapset ja nuoret käyttävät päivittäin kulttuuriharrastuksiin tai perheen kanssa seurusteluun.

Tilastokeskuksen ajankäyttötutkimuksen mukaan alle 15-vuotiailla lapsilla ja nuorilla on päivittäin kahdeksan tuntia vapaa-aikaa. Tästä vanhempien ja sisarusten kanssa seurusteluun käytetään seitsemän minuuttia keskimäärin, joka päivä. Lähes yhtä vähän 


\section{Anna Anttila}

aikaa alle 15-vuotiaat käyttävät erilaisiin kulttuuri- ja huvitilaisuuksiin osallistumiseen: kahdeksan minuuttia. Ja tähän alle kymmenen minuutin päivittäiseen kulttuuritilaisuuksien annokseen kuuluu myös esimerkiksi elokuviin tai urheilutilaisuuksiin liittyvä matkanteko. Suurimman painoarvon lasten vapaa-ajankäytössä saavat perheen ulkopuoliset sosiaaliset verkostot sekä heidän omat harrastuksensa, kuten lukeminen ja liikunta, televisio- ja muu sähköinen viihde.

Teknisen kehityksen ja tietoverkkojen tarjonnan laajentumisen vuoksi sähköiseen muotoon, kuten Internetiin, siirtyy sosiaalisen kanssakäymisen lisäksi muitakin vapaaajan toimintoja. Netissä voi esimerkiksi lukea lehtiä, kuunnella musiikkia tai katsella televisiota ja elokuvia. Kommunikointi toisten ihmisten kanssa on kuitenkin kaikkein suosituin tietokoneen käyttötarkoitus. Toiset lapset vaikuttavat lapseen ja hänen sosiaalistamiseensa jopa enemmän kuin varsinaiset kasvattajat, ja myös tietoverkkojen ulkopuolella.

Varhaisnuoruus, eli vuodet varhaislapsuuden ja varsinaisen nuoruuden välissä siis noin 7-13-vuotiaana - on vähän tutkittu elämänkaaren vaihe. Psykologiassa ja kasvatustieteissä on kohdistettu enemmän mielenkiintoa muutamaan ensimmäiseen ikävuoteen sekä toisaalta ongelmallisena pidettyyn murrosikään ja aikuistumisen pullonkauloihin.

Vaikka väliin jäävä varhaisnuorten ikäryhmä on ollut käyttäytymistieteellisen tutkimuksen marginaalissa, kulttuurisena ilmiönä ja nimenomaan jälkiteollisen ajan synnyttämänä ikäkautena varhaisnuoruus on mielenkiintoinen. Lapsuuden murros ja elinpiirin laajeneminen sekä varhaisnuorten rikas oma folklore tarjoavat humanistille antoisan tutkimuskohteen. Tutustumalla empiriaan, eläviin lapsiin ja heidän kertomuksiinsa, olen kulttuurintutkijana päässyt lähelle sitä kiehtovaa maailmaa, josta varhaisnuoren oma perhe saa osakseen vain seitsemän minuuttia päivässä. Ikäryhmän omaehtoisissa toimissa ja elämyksissä sekoittuvat leikinomaisuus ja kiinnostus nuorisokulttuuriin sekä pyrkimys luoda nuorisokulttuurisia käytäntöjä. Varhaisnuorilla on runsaasti omaa perinnettä kuten vitsejä, rituaalisia ennustusleikkejä ja roolipelejä. Perinne tarjoaa kulttuurisia malleja, jotka muovaavat myös tunne-elämän osa-alueita.

Tarkempana tutkimusaiheenani ovat olleet vuosituhannen vaihteen tyttöjen rakkausennustukset sekä 7-13-vuotiaiden varhaisnuorten romanttinen seurustelukulttuuri eli kuten ala-asteikäiset sitä itse kutsuvat: "kimpassa oleminen".

Käytin tutkimuksessani 1970-luvulla alkaneen folkloristisen lastenperinteen tutkimuksen ja vuosituhannen vaihteen tyttötutkimuksen teorioita ja menetelmiä. Liitin yhteen tasa-arvoon pyrkivän, naistutkimukseen pohjaavan tyttötutkimuksen ja relativistisen antropologian ja folkloristiikan näkökulmia. Näistä tieteidenvälisistä ja monitieteellisistä vaikutteista työhöni muodostui kehys, jota kutsun sisaruus- tai siskoustutkimukseksi. Siskoustutkimukseni kiinnittyy tieteen kentällä sekä sukupuolijärjestelmään että sukupolvijärjestelmään, koska pohdin sekä tyttöyttä ja naiskulttuuria että varhaisnuoruuden ikäkautta. Siskous yhdistää tässä tutkimuksessa eri sukupolviin kuuluvat tytöt ja naiset paitsi toisiinsa, myös poikiin. Toisin kuin tyttötutkimuksissa yleensä, olen perehtynyt myös poikien näkökulmiin. Sisko voi olla aikuinen tai lapsi ja siskolla voi olla veli. 
Tutkimukseni arvostaa niin sanotun uuden lapsitutkimuksen paradigman mukaisesti tytön nykyisiä kykyjä ja käsityksiä sinällään, ei vain merkkeinä siitä, minkälainen lapsesta ominaisuuksiensa tai kokemustensa perusteella joskus aikuisena tulee. Siskoustutkimuksessa tyttöjä voi tarkastella samoin menetelmin kuin naisia, koska aikuisuuteen kasvamisen ja sosialisaation näkökulmaa ei painoteta.

Yleensä lapsuustutkimukset sivuuttavat ihastumiset ja rakastumiset täysin. Lasten rakkaudentunteita ei länsimaissa ole otettu vakavasti. Kuitenkin nimenomaan tyttökulttuuri on täynnä tulenpalavia tunteita. Tyttöjen perinteen monet lajit liittyvät rakkauteen eli tykkäämiseen. Arvokkaita naiskokemuksia ja seurustelusuhteita aletaan kartuttaa jo peruskoulun alaluokilta lähtien, mutta vasta peruskoulun yläluokilla alkavat fyysisemmät seurustelusuhteet, joita esimerkiksi lukiolaiset pitävät "oikeana" seurusteluna. Itse kimpassa oleville rakkauteen perustuva parisuhde on tietenkin ihan oikea, vaikka fyysinen kontakti puuttuukin.

Varhaisnuorten seurustelukulttuurissa näkyy parisuhdetta arvostava länsimainen kulttuuri, jonka aineksista lapset rakentavat itselleen sopivan kimpassa olemisen tavan. Monet varhaisnuorten seurustelukulttuurin ilmaisutavat ovat vastakohtaisia aikuisten seurustelun malleille. Varhaisnuorten seurustelussa ja ennustusleikeissä suhteen onnenhetket on mahdollista jakaa tyttöjen kesken. Naisilla sen sijaan on tapana ennemminkin puida yhdessä nimenomaan suhteen vaikeuksia ja jättää onnenhetket intiimin puolelle.

Tytöt voivat järjestellä ja käydä suhteita läpi keskenään esimerkiksi pelikorttien avulla povaamalla tai rakkausprosentteja laskemalla. Kimpassa olevien ei välttämättä odoteta tapaavan toisiaan kertaakaan tai toisen osapuolen, pojan, ei lainkaan tarvitse tietää seurustelevansa. Pojat kuitenkin arvostavat kimpassa olemista. Romanttisen kulttuurin kunnioitus koko ikäryhmän sisällä osoitti, että 1990-luvulla tyttömäinen perinne ja tyttökulttuurin asema olivat vahvistumassa.

Ilmiönä varhaisnuorten romanttinen seurustelu toteutuu vähintäänkin ajatusten ja puheen tasolla, mielessä. Tämä ajatustodellisuus synnyttää taas ajatuksia ja tunnetiloja, vaikkei aikuisnäkökulmasta oikeaa fyysistä seurustelun todellisuutta synnyttäisikään. Yhteisön toiminnan - seurusteluun ja parisuhteisiin liittyvien pohdintojen ja käytäntöjen - tulos tuottaa yhteistä tietoa ja seurustelutaitoa. Yhteisö, esimerkiksi "koko meidän luokka", tietää ja tunnistaa seurustelevat parit. Puheen ja sopimuksen tasolla seurustelu on siis todellista ja yhteisesti jaettua kokemusmaailmaa. Myös toiminnallisen totuuskäsityksen mukaan varhaisnuorten seurustelukulttuuri on todellisuutta: jotain kollektiivista ja tuloksellista käytännön tekemistä sekä vuorovaikutuksessa jaettuja kokemuksia varhaisnuorten seurustelussa on.

Varhaisnuorten omilla keskustelupalstoilla ikäkausi näyttäytyy kovana aikana, johon vain rakastumiset tuovat onnentunteita, vain unelmat ja rakkaus tuovat lohtua ahdistavaan arkeen. Rakkaus korvaa ja poistaa kaiken kurjuuden ja tuskan, ainiaaksi. Varhaisnuorten kirjoitusten kuva rakkaudesta on hyvin satumainen: Oikea rakkaus kestää ikuisesti ja jokaisella on oikeus omaan unelmiensa prinssiin tai prinsessaan. Se Oikea istuu yleensä samassa luokkahuoneessa tai ainakin samassa koulussa. Ilman rakkautta ja parisuhdetta ei voi olla onnellinen, ehjä eikä kokonainen. Nimenomaan kaikkivoipa rakkaus onkin varhaisnuorille tärkeä ihmisoikeus. 


\section{ANNa ANTTILA}

Seurustelukulttuurin leikkikenttiä, varhaisnuorten diskoja, on lakkautettu vetoamalla niiden liian varhaiseen lasten aikuistamiseen. Lasten viattomia rakkaudentunteita on ohjattu ikätovereiden sijasta kohdistumaan esineisiin, perheenjäseniin, eläimiin tai mahdollisimman kaukaisiin idoleihin. Vanhemmilla on taipumus nähdä oma ja varsinkin esipolvien lapsuus nostalgisten silmälasien läpi, jotenkin viattomana, onnellisena, tunne-elämältään rikkaampana ja jopa jotenkin aidompana kuin nykyinen lapsuus. Viattomuuden ideaali vaatii parikseen viallisuuden ja turmiollisuuden eli väärän lapsuuden ja väärät leikit. Viattoman lapsuuden ideaali luo myös lasten kielletyt leikit.

Aikuisten käsitykset lasten rakkaus- ja seurusteluleikkien viallisuudesta perustunevat heidän omiin kullattuihin lapsuusmuistoihinsa tai korkeintaan noin seitsemän minuutin päivittäisiin keskusteluihin elävien lasten kanssa, eivät kokemuksiin kentältä. Viattomuus liitetään tietämättömyyteen; lapsuus on aikaa, jolloin ollaan onnellisen tietämättömiä, yleensä kaikesta. Tietoiseksi tulemiseen liittyy häpeän kokemuksia, kun oma tietämättömyys ja sinisilmäisyys paljastuvat. Pitämällä lapset tietämättömyydessä aikuiset vahvistavat valta-asemaansa.

Lapset ovat erityisryhmä, jolla ei jo sinällään ole riittäviä ihmisoikeuksia. Kaksikymmentä vuotta sitten heille on säädetty oma, erillinen lapsen oikeuksien sopimus. Kun aikuisuudesta käsin ja lainsäädännön turvin on saneltu, mihin lapsella nimenomaan lapsena on oikeus, on ilmaistu myös se, mihin hänellä ei pelkästään ihmisenä jo olisi YK:n ihmisoikeusjulistuksen mukaan oikeutta. Yhteiskunnallisessa lapsuusdiskurssissa näkökulma on sukupolvijärjestelmän mukaisesti hierarkkinen. Korkeammalla yhteiskunnallisella tasolla olevien ääni kuuluu ja polttopiste on nimenomaan aikuisten jälkeläisissä ja näiden jälkeläisten saattamisessa tasapainoiseen aikuisuuteen. Lapsilta ei välttämättä kysytä, mikä tällä matkalla ja sen taukopaikoilla on parasta, tai mihin kulttuurin osa-alueisiin he itse haluaisivat saada oikeuden jo sinällään arvokkaassa elämänvaiheessaan, lapsuudessa. Vaikka lapsilla on YK:n yleiskokouksessa hyväksytyt erityisoikeudet, heidän elämänsä nähdään valitettavan usein vain valmistautumisena varsinaiseen ihmiselämään, mitä ilmeisesti ainoastaan keski-ikäisyys edustaa.

Sen sijaan - onneksi - meidän keski-ikäisten, entisten lasten, on varsinaisessa elämässämme edelleen sallittua jatkaa oman sisäisen lapsemme elämää ja ylläpitää hänen hyvinvointiaan.

Anttila, Anna 2009: Leikin asia. Näkökulmia varhaisnuorten romanttiseen seurustelukulttuuriin. Helsinki: Yliopistopaino. Helsingin yliopiston sähköinen väitöskirja [online] $<$ https://oa.doria.fi/bitstream/handle/10024/46858/leikinas.pdf?sequence $=1>$.

Filosofian tohtori Anna Anttila on helsinkiläinen folkloristiikan tutkija. 